\title{
Reproductive aspects of yellow fish Girardinichthys multiradiatus (Meek, 1904) (Pisces: Goodeidae) in the Huapango Reservoir, State of Mexico, Mexico
}

\author{
Cruz-Gómez Adolfo", Rodríguez-Varela Asela del Carmen, Vázquez-López Horacio \\ Laboratorio de Ecología de Peces, Facultad de Estudios Superiores Iztacala, UNAM, Av. De Los Barrios, No. 1, Los Reyes Iztacala, \\ Tlalnepantla, Estado de México, México, C. P. 54090
}

\section{Email address:}

adolfocg@servidor.unam.mx(A. Cruz-Gómez), asela@servidor.unam.mx(A.del C. Rodríguez-Varela), hvazquez@campus.iztacala.unam.mx(H. Vázquez-López)

\section{To cite this article:}

Cruz-Gómez Adolfo, Rodríguez-Varela Asela del Carmen, Vázquez-López Horacio. Reproductive Aspects of Yellow Fish Girardinichthys Multiradiatus (Meek, 1904) (Pisces: Goodeidae) in the Huapango Reservoir, State of Mexico, Mexico. American Journal of Life Sciences, Vol. 1, No. 5, 2013, pp. 189-194. doi: 10.11648/j.ajls.20130105.11

\begin{abstract}
The sexual maturity, age at first maturation and fecundity in females of the yellow fish Girardinichthys multiradiatus were analyzed in the Huapango reservoir located in the State of Mexico, Mexico. From July 2007 to May 2008 bimonthly samplings were carried out and, using a bait well net, 407 individuals were collected (245 females and 162 males). Overall, the sex ratio between females/males was 1.51:1 $(P<0.05)$. The age of first maturation in the females was $33 \mathrm{~mm}$ of standard length. The spawning period occurred in July and accounted for the highest values in the gonadosomatic index. For the fertility model only fertilized eggs and embryos were considered, and those were adjusted to the potential model $\mathrm{F}=1 \mathrm{E}-08 \mathrm{~L}^{5.6144}(P<0.05)$. This study contributes to the understanding of the reproductive biology of the yellow fish, which takes place in the reservoirs of the State of Mexico.
\end{abstract}

Keywords: Girardinichthys Multiradiatus, Sex Ratio, Fecundity, Sexual Maturity

\section{Introduction}

Goodeidae family gathers 42 species of Mexican endemic freshwater fish, characterized among other things by presenting marked sexual dimorphism, premarital courtship and viviparity, phenomena that involve a series of morphological, anatomical and physiological adaptations, that are characteristic of the group [9]. Goodeidae family is one of the richest in endemicity and represent $32 \%$ of the endemic species of the Mesa Central of Mexico [8, 10], of these, Girardinichthy multiradiatus is commonly known as "the Lerma mexcalpique" or "yellow fish", and it is distributed in the top of the basins of the rivers Balsas, Lerma-Santiago and Panuco in the states of Mexico, Michoacán and Querétaro and that, according to the red List of Threatened Species [14], is listed as an endangered species.

In the State of Mexico, the environments in which this species is located are systems with little movement in its waters, with riverside or submerged vegetation and depths lesser than a meter, in addition to ponds or ditches [19].
These features coupled with urban settlements, agricultural activities, water extraction and introduction of exotic species, have put at risk the native species of this region, which has led to the disappearance of the fauna and flora in some lakes and reservoirs [31, 6]. Despite being an endemic species whose habitat is at risk due to human activities, $G$. multiradiatus has been little investigated, except for feeding, and only a few researchers have considered it threatened [4] and others think that it is not at risk [8]. In this sense, it has been mentioned that the existing information on the reproductive biology and ecology of the species is scarce, limiting the knowledge of this species in order to develop conservation and/or domestication strategies for commercial purposes [32].

Among the studies that have been made about $G$. multiradiatus we can mention behavior, feeding, and biology, but very few about its reproductive biology have been carried out; among the most remarkable works we can highlight the ones of Reference [16, 3, 17, 5, 22, 32, 21, 6, 7]; for other goodeids we can include the studies of Reference [18] and Reference [20], in addition to those reported by Reference [33], [34] and Reference [35] in their compilation 
of viviparous fishes.

In this regard, Reference. [33] mentioned that the study of reproduction biology constitutes an essential aspect in understanding animal species, since this aspect defines their permanence in the habitat and the balance of their populations; that is the reason why the objective of this study was to contribute to the knowledge of the reproductive aspects of $G$. multiradiatus in Huapango reservoir in the State of Mexico, and obtain information that will allow the conservation of this endemic species of Mexico.

\section{Material and Methods}

\subsection{Study Area}

Huapango is a reservoir located in the State of Mexico, in the municipality of Timilpan, between Longitude W $99^{\circ} 42$ '07" and Latitude N 20 00' 24", at an altitude of 2623 masl (meters above sea level). The predominant climate is temperate sub-humid with summer rains, and it is considered one of the wettest in this category, as its total annual rainfall exceeds $800 \mathrm{~mm}$ of rainfall level; in addition, the prevailing winds are from north to south, and the average annual temperature is $13.8^{\circ} \mathrm{C}$, with a maximum of $36^{\circ} \mathrm{C}$ and a minimum of $-4^{\circ} \mathrm{C}$ with frosts from October to May. In this region, there are two very distinct climatic seasons: the dry season from November to March and the rainy season from April to October [28].

The sampling site was selected according to the criterion of Reference. [19]. On the chosen site, bimonthly samplings were carried out from July 2007 to May 2008 and in each of them an area of $13.5 \mathrm{~m}^{2}$ on submerged vegetation was sampled, the trawling was made with a bait well net with dimensions of $45 \times 25 \mathrm{~cm}$ in the mouth, depth of $30 \mathrm{~cm}$ and 2 $\mathrm{mm}$ mesh; the captured specimens were fixed in formaldehyde $10 \%$ [2]. All organisms were sexed, measured in its pattern length $( \pm 0.1 \mathrm{~mm})$ and weighed on a digital balance ( $\pm 0.001 \mathrm{~g})$. With the data obtained, the gonadosomatic index (GSI) and condition factor (CF) were calculated according to the criterion of Reference [24]. The sex ratio was calculated using monthly data and the degree of significance was established using the Chi-square test $\left(\mathrm{X}^{2}\right)$ with $p<0.05$ [38].

For the elaboration of growth and fertility models, all organisms were grouped into size frequency intervals of 3.0 $\mathrm{mm}$ [6]. After the dissection of the incubation chamber, they were separated and counted the immature eggs (oocytes), mature eggs (ova), embryonated eggs and embryos. The fertility model was obtained with the data from embryonated eggs and embryos, which was adjusted to the potential model $\mathrm{F}=\mathrm{aL}^{\mathrm{b}}[13,27,37]$. Finally, $\mathrm{d}$ the logistic equation $\mathrm{P}$ $=100 / 1+e^{a+b L}$ was used to calculate the size of the first reproduction $[1,26]$.

\section{Results}

407 individuals were captured, 245 females $(60.20 \%)$ and 162 males $(39.80 \%)$ with a sex ratio of 1.5 females for each male and only in the months of July and March the sex ratio was reversed (Table 1). The length and weight averages obtained for the females during the sampling period are shown in table 2, in general the larger sizes were collected during March and July and the smaller during September. The monthly gonadosmatic index is shown in Fig. 1; the highest values correspond to July and September and the lowest November. Fig. 2 shows the monthly Condition Factor observed maximum values during July, May and November. Fig. 3 shows the percentages in the monthly variation of the stages of maturity; immature eggs (oocytes), mature eggs, fertilized (with embryo) eggs and embryos, the values observed during September and November correspond to immature fish. Fig. 4 shows the percentages by size for stages of immature eggs, mature eggs, fertilized eggs and embryos, note that embryos begin to appear in the size of $30 \mathrm{~mm}$. The logistic model of Fig. 5 shows the size of first maturation which was $33 \mathrm{~mm}$, which is consistent with that observed in Fig. 4. On the other hand, the model of fertility which is shown in Fig. 6 was adjusted to the potential form $\mathrm{F}=1 \mathrm{E}-08 \mathrm{~L}^{5.6144}$

Table 1. Total number of individuals and monthly sex ratio.

\begin{tabular}{llllll}
\hline & Females & Males & Sexual \% F/M & Expected & $\mathbf{X}^{2}$ \\
\hline July & 39 & 47 & 0.83 & 43 & 0.37 \\
September & 46 & 10 & 4.60 & 28 & 11.57 \\
November & 26 & 15 & 1.73 & 20.5 & 1.48 \\
January & 53 & 31 & 1.71 & 42 & 2.88 \\
March & 28 & 31 & 0.90 & 29.5 & 0.08 \\
May & 53 & 28 & 1.89 & 40.5 & 3.86 \\
Total & 245 & 162 & 1.51 & 203.5 & 8.46 \\
\hline
\end{tabular}

Table 2. Monthly averages in length and weight for females

\begin{tabular}{|c|c|c|c|c|c|c|c|c|}
\hline & \multicolumn{3}{|c|}{ Length (mm) } & \multicolumn{5}{|l|}{ Weight (g) } \\
\hline & minimum & mean & DS & maximum & minimum & mean & DS & maximum \\
\hline July & 34.00 & 41.35 & 4.12 & 49.00 & 1.45 & 2.21 & 0.66 & 3.43 \\
\hline September & 8.70 & 15.85 & 3.96 & 23.10 & 0.01 & 0.11 & 0.11 & 0.28 \\
\hline November & 16.50 & 22.75 & 3.97 & 34.80 & 0.62 & 0.22 & 0.09 & 0.95 \\
\hline January & 15.00 & 20.34 & 2.54 & 28.40 & 0.08 & 0.17 & 0.07 & 0.43 \\
\hline March & 18.00 & 22.84 & 2.57 & 27.40 & 0.10 & 0.24 & 0.09 & 0.40 \\
\hline May & 20.20 & 25.16 & 4.17 & 45.50 & 0.19 & 0.44 & 0.34 & 2.55 \\
\hline
\end{tabular}




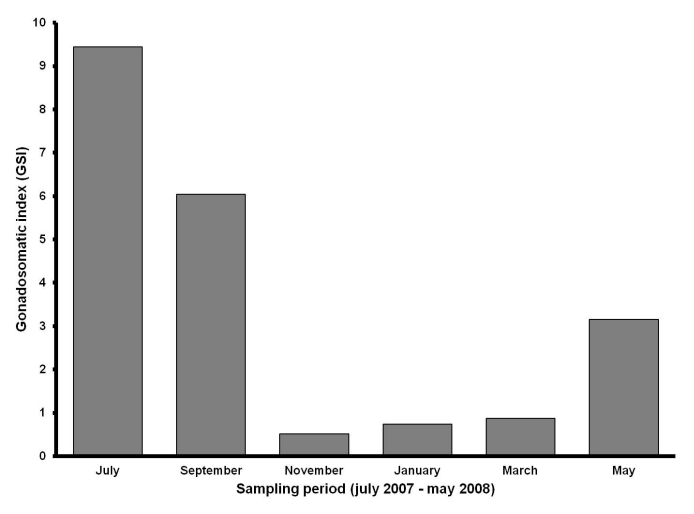

Figure 1. Values of gonadosomatic index (GSI).

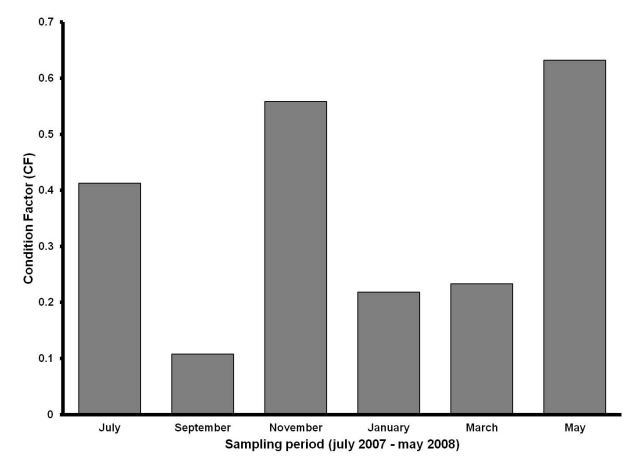

Figure 2. Monthly values of Condition Factor (CF).

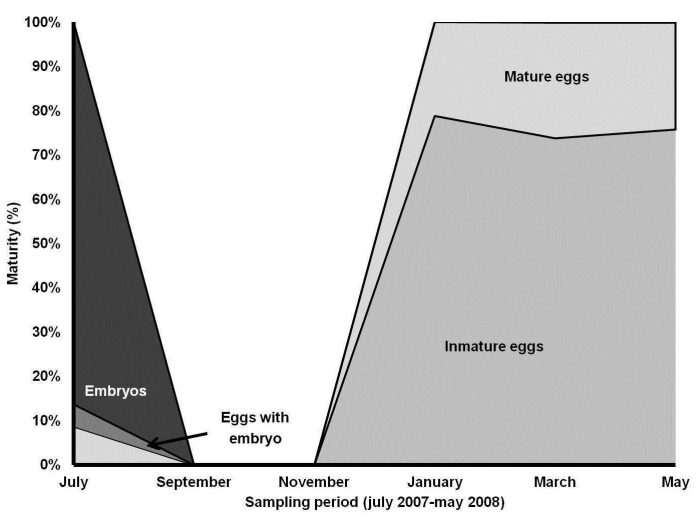

Figure 3. Percentages of monthly maturation of immature eggs stadiums, mature eggs, fertilized (with embryo) eggs and embryos.

\section{Discussion}

Overall, the sex ratio favored to females; however this proportion changes monthly as shown in Table 1, which shows July and March with the sex ratio favoring males (0.83 and 0.90 respectively). Reference $[6,7]$ reported a similar sex ratio for this species in reservoirs of San Martín in the state of Querétaro and in Villa Victoria, State of Mexico (1.7:1 and 2.27:1 respectively). The sex ratio favoring females is also reported for other goodeids; of 1.5:1 and 4:1 for Hubbsina turneri De Buen, 1941 [20], but for Zoogoneticus quitzeoensis Bean, 1898, this ratio was 1:1

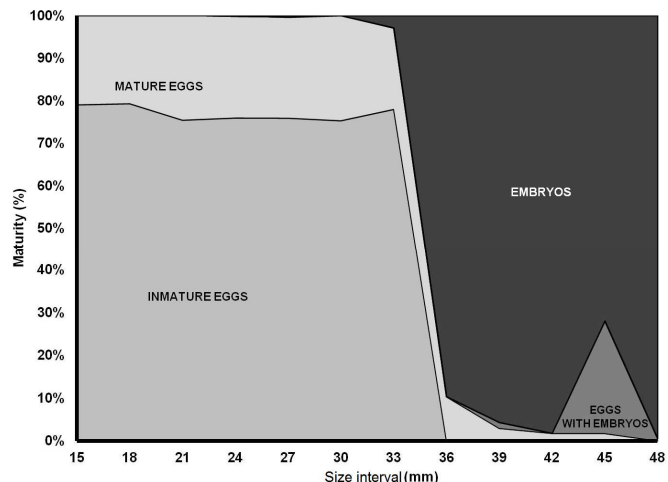

Figure 4. Percentages of maturity size obtained during the sampling period.

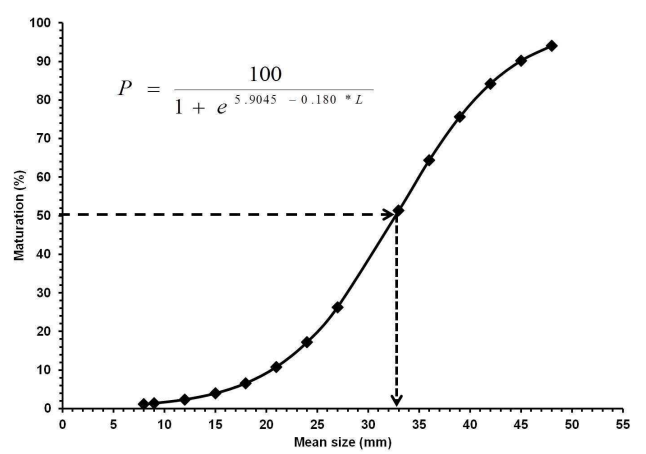

Figure 5. Logistic model for obtaining the size of G. multiradiatus at first reproduction.

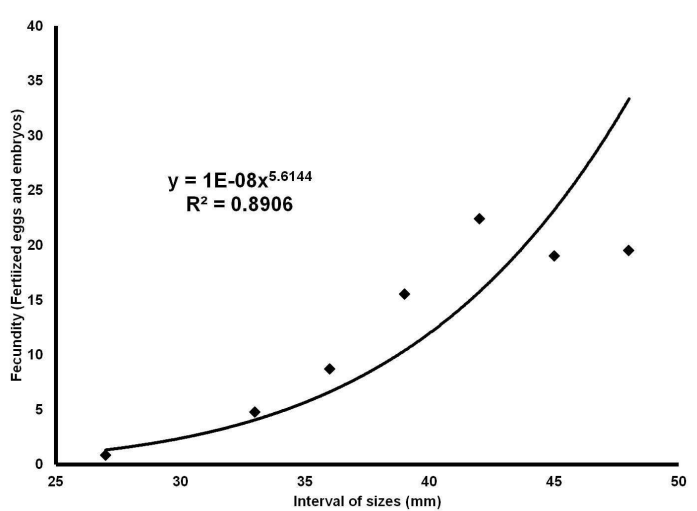

Figure 6. Fertility model of G. multiradiatus obtained from the data of eggs with embryo and embryos.

[23]. Another report, in which the sex ratio in general favors males, was recorded at the reservoir of San Miguel Arco, State of Mexico with sex ratio males/females of 1.39:1 [21]. For other ovoviviparous species Reference [12] reported a sex ratio of $1.7: 1$, in favor of females in Heterandria bimaculata Heckel, 1848. In this regard, Reference [30] mentioned that in Poeciliids (viviparous and ovoviviparous species) the sex ratio in general favors females in wild populations, which allows them to ensure the reproduction. But he also mentions that the changes related to the sex ratio may be due, among other things, to the size of the males and their feasibility in the catch, to the segregation in the habitat 
by sex and to the predation toward males; the latter was also reported by Reference [15] which might happen to this species and explain the different values of the reported sex ratio for this species. In this sex ratio also influences the use of different trapping methods used in various systems, where seines or bait well nets are used.

Furthermore, the corporal indices that have been introduced searching for a simple and objective criterion to quantify the gonadal development are useful for identifying the time of spawning, especially in species which have a marked seasonality [26] which apparently is the case with this species. In this case, the highest values of the GSI, also called coefficient of maturity (9.43 in July, 3.15 in May), correspond to the sizes of larger females, captured in these months (41.35 mm in July, $25.16 \mathrm{~mm}$ in May), as well as also with values higher in the CF ( 0.41 in July, 0.63 in May), months in most big and pregnant females were captured (Figs. 2 and 3). Similar values are reported for Ameca splendes [22] and H. turneri [20]. Reference [26] also mentions that seasonality may be more marked in systems water, less stable, as it occurs in the reservoirs in the State of Mexico, which are subject to a variation in their volumes due to the extraction of water for irrigation.

In this paper, the results indicate a breeding season for the yellow fish from May to September (Fig. 3), coinciding with data reported by Reference [21] in the Reservoir of San Miguel Arco in the State of Mexico and Reference [6, 7], in San Martin, Querétaro and Villa Victoria, State of Mexico. These are also the months where, in addition, the highest values of GSI are observed (Fig. 1). For other goodeids species, Reference [18] and Reference [22] report a reproductive season similar to the G. multiradiatus. However, these data differ from those reported by Reference [19] who reported a period of reproduction from December to May, while Reference [17] mentioned that the reproductive cycle of this species has a period of continuous reproduction. However, in none of these cases it is mentioned whether the data correspond to annual samplings as the ones of the present paper. In this and in the above mentioned reservoirs, the reproduction is interrupted from November to February, month in which the lowest temperatures are registered in the area, ranging from $9-12^{\circ} \mathrm{C}$, corresponding to the dry season [29]. This information is consistent with what Reference [9] reported for Girardinichthys viviparous; they indicate that during these months an interruption in the reproduction of this species can be observed due to environmental effects. In contrast, Reference [12] indicate that the maximum period of viviparous reproduction for some fish is related to the increase in the water level and temperature, as it occurs in these bodies of water and in this region in particular, which temperature and water level begin to increase from May to October, representing the rainy season in the area [29].

On the other hand, the average size observed along the sampling was $24.95 \mathrm{~mm}$, similar to the one observed in the reservoir of San Martín (20.4 mm). This is because during the dry season is more evident the absence of adult specimen, due to the low water levels of these systems, especially in
San Martin which is emptied almost in 90\% [6].

The maturity percentages show that the gonads of the organisms with size range of $15-30 \mathrm{~mm}$ (Fig. 4) begin to mature or have already matured and, moreover, the apparition of fertilized eggs and embryos in organisms with size of $33 \mathrm{~mm}$ (10 embryos in average) suggests that this is the size of maturity onset, and this is evidenced in the model obtained from the maturity data. Reference $[6,7]$ found that the size of $G$. multiradiatus at first reproduction in the reservoir of San Martin, Querétaro was of $30 \mathrm{~mm}$ with 18 embryos on average and in Villa Victoria, State of Mexico, was of $32 \mathrm{~mm}$ also with 18 embryos on average. The maximum number of embryos observed in this study was 68 , in sizes of $47 \mathrm{~mm}$, while Reference [21] reported 87 embryos in San Miguel Arco. For other goodeids, Reference [23] reported for Z. quitzeoensis a maturation size of $30 \mathrm{~mm}$, but an average of 10 embryos; this is the lowest average for goodeids. Reference [18] reported an average of 20 embryos for Allophorus robustus and Goodea luitpoldii and 40 embryos in average for Neophorus diazi. Furthermore, Reference [34] reported an average of 30 embryos in Ilyodon whitei and 55 in Goodea atripinnis. In this regard, Reference [26] mentions that the age and size of first maturity can vary within the same species, and that this variation may be spatial or temporal; in addition, he refers to the fact that populations of the same species have different values in different areas of their distribution range, as it has been mentioned for the different systems in which $G$. multiradiatus has been studied.

The fertility model (Fig. 6) showed similar information to what has been reported for G. multiradiatus in the reservoir of San Martin, Querétaro [6], and shows a direct relationship between the number of embryos and the size of the organisms. In this sense, the fertility model as it applies to the oviparous species was not applied to G. multiradiatus, given the viviparous characteristics of this species. In this type of fishes is common to observe a decrease in the number of eggs as sexual maturity advances to give way to the number of embryos to be born, due to which fecundity (fertility) in these organisms should be referred to the complex consisting of embryonated eggs and embryos at different stages in development found at the time of capture and preservation. According to this, it is better to refer to the concept of fertility [27, 12, 36], for viviparous and ovoviviparous species, where the effective number of embryos to be born and their relation to the size are shown. However, more studies on fertility in viviparous and ovoviviparous species need to be considered in order to establish differences or similarities in the reproductive behavior of these species and to establish the proposed model of fertility.

The results in this study do not differ from those reported for the reservoirs of San Martin and Villa Victoria, both in CF and GSI (Figs. 1 and 2), which reflect the physiological conditions of the yellow fish and showed a direct relationship with the female size and its maturity; this variation indicates that the reproductive period of the yellow fish occurs from 
May to September (Fig. 3), because after the reproductive period, there is an increment of immature organisms and organisms in maturing process with sizes that are smaller than the size of first maturity (33 mm) (Figs. 4 and 5). Likewise, values of fecundity and size at first sexual maturity, as mentioned above, differ slightly from the different systems studied.

GSI values reflect the development of the gonads and could well be used as an indicator of gonadal maturation, just as the $\mathrm{CF}$ that is related to GSI could be considered as a complement to gonadal maturity stages in this species. These data suggest that both the GSI and CF (Figs. 1 and 2) can be used to determine the degree of maturity and identify the time of egg-laying of the yellow fish, as mentioned by Reference [26] for species of seasonal egg-laying and, in this case, a seasonal breeding period can be clearly observed (Fig. 3). Studies on these parameters (CF and GSI) were carried out in Ameca splendes [22] and H. turneri [20]. They also show a relationship with maturity stages, similar to those reported in this study for G. multiradiatus.

The above mentioned is indicative of the particularity and dynamical environments in which some freshwater species develop. As in this case, it is likely that variations in the water level due to the use of water for irrigation during the dry months, coupled, among other factors, with climatic seasons and productivity in systems, may influence the reproductive aspects of the yellow fish, not only from a physiological point of view, but also from a behavioral standpoint. This applies not only to this species but to most goodeids subject to habitat modification and whose geographic range is restricted [8].

The conservation of goodeids is an important work that should be done, but it seems difficult due to the scarcity of studies on reproduction of the species and to the irrational use of natural resources that damage their habitat [11]. In this sense, some authors mention that aquaculture can be considered as a tool for the conservation of endemic and endangered native species, but based on the knowledge of their biology and establishing techniques that allow their cultivation [25], studies of this nature are necessary to protect endangered species.

\section{Acknowledgements}

In order to accomplish this work, we had the support of the programs of the National Autonomous University of Mexico: Support Program to Career Teachers to Promote Research Groups (PAPCA) and Support Program to Institutional Projects for the Improvement of Education (PAPIME) Project EN203804 of DGAPA.

\section{References}

[1] H. Arancibia, L. Cubillos, J. Remmaggi and R. Alarcón, "Determinación de la talla de primera madurez sexual y fecundidad parcial en la sardina común, Strangomera bentincki (Norman, 1936), del área de Talcahuano, Chile", Biología Pesquera, vol, 23, pp. 11-17. 1994.
[2] T. B. Bagenal (Ed) Methods for assessment of fish production in fresh waters. 3rd Ed. Blacwell Scientific Publications Oxford.

[3] T. Burt and C. Macias-García, "Amarillo fish (Girardinichthys multiradiatus) Use visual landmarks to orient in space" Ethology, vol. 109(4), pp. 341-350. 2003

[4] S. Contreras-Balderas y P. Almada-Villela, "Girardinichthys multiradiatus". In: IUCN 2013. IUCN Red List of Threatened Species, versión 2011,1. (www.iucnredlist.org).

[5] A. Cruz-Gómez, A. C. Rodríguez-Varela y D. García-Martínez, "Las larvas de insectos en la dieta de Girardinichthys multiradiatus (Pisces: Goodeidae) en el embalse Ignacio Ramírez, Estado de México", Entomología Mexicana, vol. 4, pp. 1002-1006, 2005.

[6] A. Cruz-Gómez, A. C. Rodríguez-Varela y $\mathrm{H}$. Vázquez-López, "Madurez sexual y reproducción de Girardinichthys multiradiatus (Meek, 1904) en un embalse del poblado de San Martín, Querétaro, México" BIOCYT, vol. 3(9), pp. 94-106, 2010.

[7] A. Cruz-Gómez, A. C. Rodríguez-Varela y H. Vázquez-López H, "Reproductive aspects of Girardinichthys multiradiatus, meek 1904 (Pisces: Goodeidae)", BIOCYT, vol. 4(13), pp. 215-228, 2011.

[8] M. Y. De la Vega-Salazar, "Estado de conservación de los peces de la familia Goodeidae (Cyprinodontiformes) en la mesa central de México", Revista de Biología Tropical, vol. 54(1), pp. 163-177, 2006.

[9] E. Díaz-Pardo y D. Ortíz-Jiménez, "Reproducción y ontogenia de Girardinichthys viviparus (Pisces: Goodeidae)", Anales de la Escuela Nacional de Ciencias Biológicas, vol. 30(1-4), pp. 45-67, 1986.

[10] O. Domínguez-Domínguez, I. Doadrio and G. Pérez-Ponce de León, "Historical biogeography of some river basins in central Mexico evidenced by their goodeine freshwater fishes: a preliminary hypothesis using secondary Brooks parsimony analysis" Journal of Biogeography vol. 33, pp. 1437-1447, 2006.

[11] O. Domínguez-Domínguez y G. Pérez-Ponce de León, "Los goodeidos, peces endémicos del centro de México", CONABIO Biodiversitas, vol. 75, pp. 12-15, 2007.

[12] J. L. Gómez-Márquez, J. L. Guzmán-Santiago y A. Olvera-Soto, "Reproducción y crecimiento de Heterandria bimaculata en la laguna "El Rodeo", Morelos, México" Revista de Biología Tropical, vol. 47(3), pp. 581-592, 1999.

[13] M. J. Holden y D. F. S. Raitt, "Manual de ciencia pesquera Parte 2 - Métodos para investigar los recursos y su aplicación”. Roma, FAO, Documento Técnico Pesca, p 211, 1975.

[14] IUCN, "IUCN Red List of Threatened Species". Version 2013.1. www.iucnredlist.org

[15] C. Macías-García, E. Saborio and C. Berea, "Does male-bias predation lead to male scarcity in viviparous fish?", Journal of Fish Biology, vol. 53(supplement A), pp. 104-117, 1998.

[16] C. Macias-García and T. Perera, "Ultraviolet-based female preferences in a viviparous fish Behavioral", Ecology and Sociobiology, vol. 52, pp. 1-6, 2002. 
[17] C. Macias-García and E. Saborío, "Sperm competition in a viviparous fish", Environmental Biology of Fishes, vol. 70(3), pp. 211-217, 2004.

[18] Mendoza G (1962) The reproductive cycles of three viviparous teleosts Alloophorus robustus, Goodea luitpoldi and Neoophorus diazi Biological Bulletin. 123(2), 351-365.

[19] Miller RR, Minckley WL, Norris SM (2005) Freshwater fishes of México. U.S.A. The University of Chicago Press. P. 136.

[20] R. Moncayo-Estrada, "Análisis histórico de la biología de la cherehuita (Hubbsina turneri) (Pisces:Goodeidae), especie endémica y en peligro de extinción de México" Revista Chapingo, Serie Ciencias Forestales y del Ambiente, vol. 18(1), pp. 101-110, 2012.

[21] N. A. Navarrete-Salgado, B. E. Cedillo-Díaz, G. Contreras-Rivero y G. Elías-Fernández, "Crecimiento, reproducción y supervivencia de Girardinichthys multiradiatus (Pisces:Goodeidae) en el embalse San Miguel Arco, Estado de México", Revista Chapingo, Serie Ciencias Forestales y del Ambiente, vol. 13(1), pp. 15-21, 2007.

[22] E. Ortiz-Ordóñez, E. Uría-Galicia, E. López-López, J. P. Maya and A. L. Carvajal-Hernández, "Reproductive cycle by histological characterization of the ovary in the butterfly goodeid Ameca splendens from the upper Río Ameca Basin, Mexico", Journal of Applied Ichthyology, vol. 23, pp. 40-45, 2007.

[23] J. P. Ramírez-Herrejón, M. Medina-Nava, C. L. Salazar-Tinoco y T. L. Z. Zubieta, "Algunos aspectos reproductivos de Zoogoneticus quitzeoensis Hubbs y Turner (1939) (Osteichtyes-Goodeidae) en la represa La Mintzita Morelia, Michoacán”, México BIOLÓGICAS, vol. 9, pp. 63-71, 2007.

[24] G. M. Rodríguez, Técnicas de evaluación cuantitativa de la madurez gonádica en peces., AGT Editor S. A. México, D.F. $79 \mathrm{p}$.

[25] R. A. Rueda-Jasso y A. Campos-Mendoza, "La acuicultura como una estrategia para la conservación de especies nativas de peces", Ciencia Nicolaita, vol. 51, pp. 55-66, 2009.

[26] F. Saborido-Rey, Ecología de la reproducción y potencial reproductivo en las poblaciones de peces marinos. Instituto de Investigaciones Marinas (CSIC) Universidad de Vigo, España. Pp. 1-71. Available from: http://digital.csic.es/bitstream/10261/7260/1/Curso\%20Ecolog ia $\% 20$ reproduccion $\% 20 \mathrm{y} \% 20$ potencial $\% 20$ reproductivo $\% 20 \mathrm{e}$ n\%20las\%20poblaciones\%20de\%20peces\%20marinos.pdf

[27] A. A. Schoenherr, "Density dependent and density independent regulation of reproduction in the gila topminnow, Poeciliopsis occidentalis (Baird and Girard)", Ecology, vol. 58 , pp. 438-444, 1977.
[28] SGGEM, (Secretaría de Gobernación y Gobierno del Estado de México), Los municipios del Estado de México. México D.F. 609 p.

[29] SMAGEM, (Secretaría del Medio Ambiente del Gobierno del Estado de México), Diagnóstico ambiental del Estado de México por regiones hidrográficas. Tlalnepantla de Baz Estado de México, 109 p.

[30] F. F. Snelson, "Social and environmental control of life history traits in poeciliid", In: Ecology and evolution of livebearing fishes (Poeciliidae), F. F. Snelson and G. K. Meffe, Nueva Jersey, Prentice-Hall, Englewood Cliffs, Pp.149-161, 1989.

[31] E. Soto-Galera, E. Díaz-Pardo, E. López-López and S. J. Lyon, "Fish as indicators of environmental quality in the Rio Lerma basin, Mexico", Aquatic Ecosystem Health and Management, vol. 1, pp. 267-276, 1998.

[32] P. Trujillo-Jiménez y E. E. D. Viveros, "La ecología alimentaria del pez endémico Girardinichthys multiradiatus (Cyprinidontiformes: Goodeidae), en el Parque Nacional Lagunas de Zempoala, México", Revista de Biología Tropical, vol. 54, pp. 1247-1255, 2006.

[33] M. C. Uribe-Aranzábal, G. De la Rosa-Cruz, S. M. Guerrero-Estévez, A. García-Alarcón y M. E. Aguilar-Morales, "Estructura del ovario de teleósteos vivíparos. Gestación intraovárica: Intraluminal en Ilyodon whitei (Goodeidae), e intrafolicular en Poeciliopsis gracilis (Poeciliidae)". In: Homenaje al Doctor Andrés Reséndez Medina. Un ictiólogo mexicano. V. M. L. Lozano and A. Contreras-Balderas, Universidad Autónoma de Nuevo León. Monterrey, México pp. 31-45, 2004.

[34] M. C. Uribe-Aranzábal, G. De La Rosa-Cruz, A. García-Alarcón, S. Guerrero-Estévez y M. Aguilar-Morales, "Características histológicas de los estados de atresia de folículos ováricos en dos especies de teleósteos vivíparos: Ilyodon whitei (Meek, 1904) y Goodea atripinnis (Jordan, 1880) (Goodeidae)", Hidrobiológica, vol. 16(1), pp. 67-73, 2006.

[35] M. C. Uribe and H. J. Grier. Viviparous Fishes II. New Life Publications México, 2010. 505 p.

[36] H. M. Urriola, P. J. Cabrera and Q. M. Protti, "Fecundidad, fertilidad e índice gonadosomático de Poecilia reticulata (Pisces: Poeciliidae) en Heredia, Costa Rica", Revista de Biología Tropical, vol. 52(4), pp. 945-950, 2004.

[37] R. J. Wootton. Fish ecology. New York, USA, Chapman and Hall, Inc. 157 p.

[38] J. H. Zar. Biostatistical Analysis $4^{\text {th }}$ Ed. Northern Illinois University, Pearson, $530 \mathrm{p}$. 